\title{
CFD Analysis of Phase Change Materials Integrated with Solar Photovoltaic Modules
}

\author{
L. Chitra, Ranjith, Abhijith, Prathyaman Singh
}

\begin{abstract}
The electrical output decreases in the PV system due to the heat generation in photovoltaic $(P V)$ cell. The part of $P V$ heat formation can be removed through attachment of phase change materials (PCM) at rear side of the ethylene vinyl acetate $(E V A)$. The paper explains the Temperature distribution in the $P V$ modules and analysis was done with and without PCM in two different weather conditions. Then the PCM (Calcium chloride hexa-hydrate) is connected on the PV panel rear side to evaluate the different solar irradiance levels. In Literature it is observed that the heat removal of PCM capability is used to control the generation of heat of the PV system. Thus the current work is to investigate the effects of PCMs in photovoltaic cell which reduces its temperature and also the thermal response of $P V-P C M$ system and various weather conditions are analysed.

Keywords-PCM, PV System, Heat Production
\end{abstract}

\section{INTRODUCTION}

$\mathbf{T}_{\mathrm{r}}$ he temperature rises in photovoltaic cell due to the solar radiation and thus the electricity conservation efficiency is reduced in the unit. The CFD analysis of phase change materials is involving for extracting the heat from PV cell to increase the efficiency of electricity. The estimation of power saving model has been designed with integrated modules of that PV module and PV-PCMs (Calcium chloride hexa-hydrate) and quantified. The most important solar radiation ratio is getting the $\mathrm{PV}$ panel by aluminum and glass covers. Utilization of solar panels, the fraction can obtain in the way of general PV manufacturing models. Then PV-PCM effective product is used to reduce the solar radiation in $\mathrm{PV}$ and aluminum container.

\section{PROPOSED METHOD}

\section{A. Phase Change Materials}

Operation of an production, PLC which is the key that is widely using tool in an industries to control and read the entire process of the plant; while in running condition of the PLC ladder program the changes in the rungs are understandable by a skilled engineer only others cause difficulties to understand the operation. So that SCADA system is implementing, through that the changes in the operation and process are easily understandable to a Client,

Revised Manuscript Received on December 30, 2019.

Dr. L.Chitra*, Professor, Department of Electrical and Electronics Engineering, Aarupadai Veedu Institute of Technology, Chennai, Tamil Nadu, India.

Ranjith, Abhijith , Prathyaman Singh , UG Students, Department of Electrical and Electronics Engineering, Aarupadai Veedu Institute of Technology, Chennai, Tamil Nadu, India. by the differentiation in color of the motor, valves, filling of liquid in pipes and more are visible to all so that less skilled operator can also be control the plant [1-3].

In practical applications, the PCM is the essential material of heat storage because of it has the characteristics of transferring high heat when crystallization and melting process that have no particular change of temperature. The PCM microcapsules captivated heat and stored in liquefied PCM, when heat increases, as well as, the PCM microcapsules discharging the stored energy then PCM gets solidify, when the heat falls [5]. Phase change process of PCM is explained in Fig.1The schematic representation of change in states such as liquid to solid as well as solid to liquid are shown in fig.1

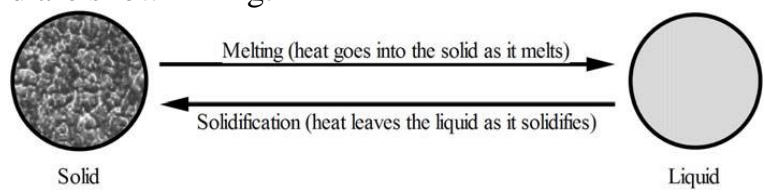

Fig. 1. Phase change schematic representation process

The change in phase processes generally occurs at the constant temperatures. This property is mainly is used in many applications. With respect to the Theory, the processed explained in various methods such as Solid-solid, Liquid-gas, solid-gas, and solid-liquid transformations.

To achieve the energy saving target, the thermal performance need to be lifted up which is highly essential. Normally this target based on cons and pros of thermal. Thermal Energy Storage system (TESS) improves thermal performance of building. PCMs for TES material are providing thermal directive by the action of absorb and emit the medium heat at certain phase change temperature. The latent and sensible are the different main methods of TES. The three steps which explain the complete TES process are as follows charging, storing and discharging. The articles are all focused; study of materials [4, 6], performance strength [7-9], optimization [10-13], heat recovery depends PCM, and effects of energy saving. The main climatic regions of PCM as well as PCM latitude ranges are in building and in different climatic regions, the major physical properties are there, the $\mathrm{CaCl}_{2} \cdot 6 \mathrm{H}_{2} \mathrm{O}$ Calcium chloride hexa-hydrate (PCM) has been selected.

\section{B. Computational Fluid Dynamics}

CFD is to solve equations and the CFD plays an important role in the modern industry and it gives more information and help to the researchers for defining and to analyze problem clearly. CFD technique uses simulation of the real time analysis so the virtual procedures and design made the work less expensive and time consuming. 


\section{CFD Analysis of Phase Change Materials Integrated with Solar Photovoltaic Modules}

In recent studies the PCM utilization in TESS and different PCM materials were explained experimentally and numerically using CFD.

The detailed experimental set up is explained in this paper. The effect of the performance for thermal changes, maintenance of temperature and improvement of PV-PCM efficiency and integrated systems was designed and analysed.

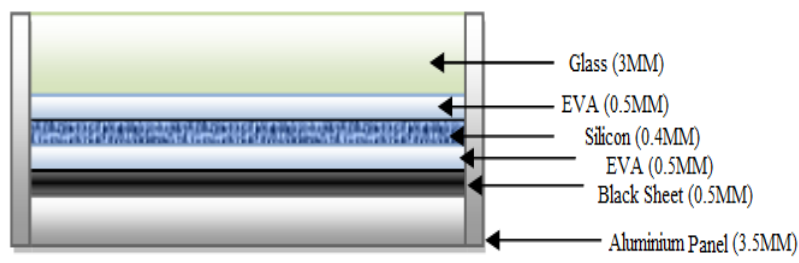

Fig. 2. Cross Sectional View without PCM Panel

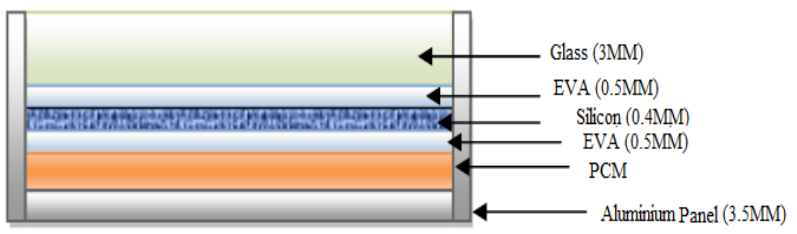

Fig. 3. PV Cross Sectional View with PCM Panel.

Types of systems such as PV panel with and without PCM have been chosen for this design. For the system with the photovoltaic panel with PCM that comprising a PV panel which set with a phase change material's container at the rear side. The other material without PCM is also analyzed. The materials thermal and physical properties such as, Length $(\mathrm{cm})$ and Thickness $(\mathrm{mm})$, specific heat capacity $\left(\mathrm{C}_{\mathrm{p} 0}\right)$, thermal conductivity $(\mathrm{K})$ and density $(\rho)$ of the material in Table 1 and Table 2.The following are the materials used Glass, ethylene vinyl acetate (EVA), Silicon, Black sheet and Aluminium.

Table: I Properties of PV Panel in Thermo-Physical

\begin{tabular}{|c|c|c|c|c|c|}
\hline Parameters & Glass & EVA & Silicon & Black Sheet & Aluminium \\
\hline $\mathrm{C}_{\mathrm{p}}$ & 500 & 2090 & 677 & 1250 & 903 \\
\hline $\mathrm{K}$ & 1.8 & 0.35 & 148 & 0.2 & 211 \\
\hline Length $(\mathrm{cm})$ & 30 & 30 & 30 & 30 & 30 \\
\hline $\begin{array}{l}\text { Thickness } \\
(\mathrm{mm})\end{array}$ & 3 & 0.5 & 0.4 & 0.5 & 3.5 \\
\hline$\rho\left(\mathrm{kg} / \mathrm{m}^{3}\right)$ & 3000 & 960 & 2330 & 1200 & 2675 \\
\hline
\end{tabular}

Table: II Thermal Properties of PCM

\begin{tabular}{|c|c|c|c|c|}
\hline Name & $\begin{array}{l}\text { Material } \\
\text { Type }\end{array}$ & $\begin{array}{l}\text { Density } \\
\left(\mathrm{kg} / \mathrm{m}^{3}\right)\end{array}$ & $\begin{array}{l}\text { CP } \\
\text { (Specific } \\
\text { Heat) } \\
- \text { J/kg-k) }\end{array}$ & $\begin{array}{l}\text { Thermal } \\
\text { Conductivity } \\
\text { (W/m-k) }\end{array}$ \\
\hline $\begin{array}{l}\mathrm{CaCl}_{2} \cdot 6 \mathrm{H}_{2} \mathrm{O} \\
\text { Calcium } \\
\text { chloride } \\
\text { hexa-hydrate } \\
(\mathrm{PCM})\end{array}$ & $\begin{array}{ll}\text { Solid } & - \\
\text { liquid } & \\
\text { Liquid } & - \\
\text { Solid } & \end{array}$ & $\begin{array}{l}1562 \\
\text { (liquid, } \\
32^{\circ} \mathrm{C} \text { ) } \\
1802 \\
\text { (solid, } \\
24^{\circ} \mathrm{C} \text { ) } \\
1710 \\
\text { (solid, } \\
25^{\circ} \mathrm{C} \text { ) }\end{array}$ & 1440 & $\begin{array}{ll}0.540 & \text { (liquid, } \\
38.7^{\circ} \mathrm{C} \text { ) } & \\
1.088 & \text { (solid, } \\
23^{\circ} \mathrm{C} \text { ) } & \end{array}$ \\
\hline
\end{tabular}

The experimental setup was designed and the analysis was conducted in the CFD ansys fluent.

\section{RESULTS AND DISCUSSION}

The main goal of CFD work as follows (i) analysis the regulations of PV temperature without PCM, (ii) Investigation of the effect of PV temperature regulations for integrated PCM systems.

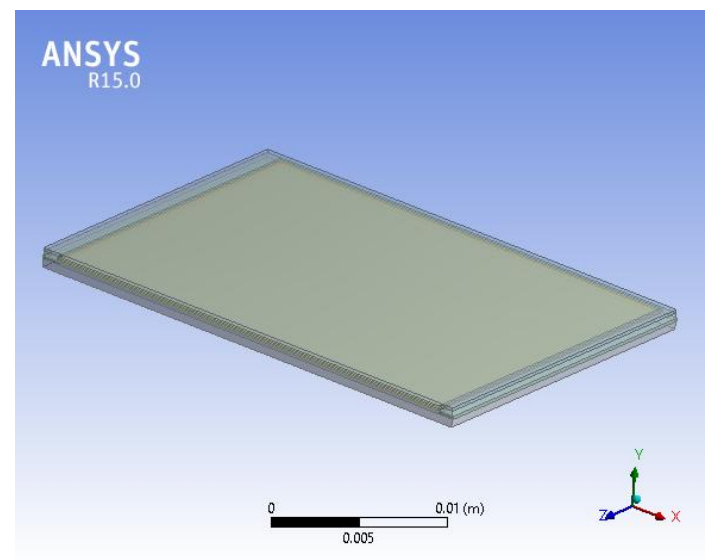

Fig. 4. Model Structure of photovoltaic panel.

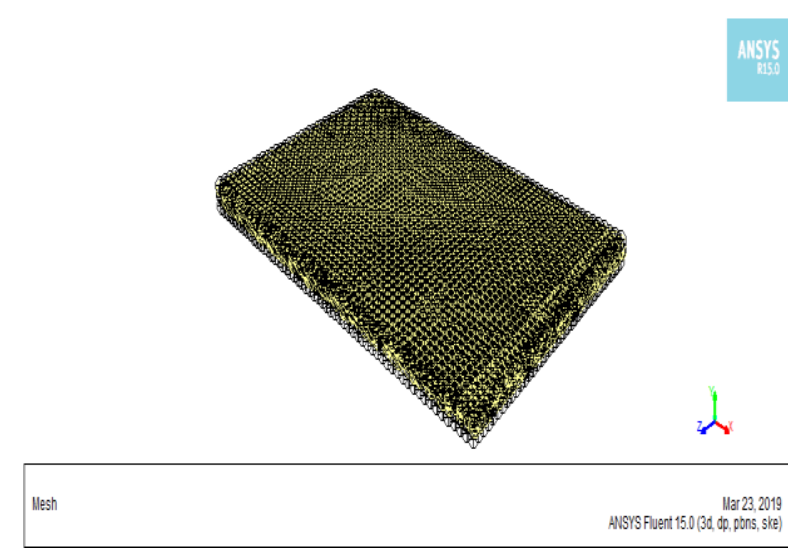

Fig. 5. Structure mesh of photovoltaic panel without

\section{PCM.}

Fig. 4 shows the computational domain PV panel without PCM and fig. 5 shows the computational grid generated around the fine mesh for boundary layer resolution. The mesh consists of 3933 quadrilateral elements with appropriate quality index and 28834 Nodes.

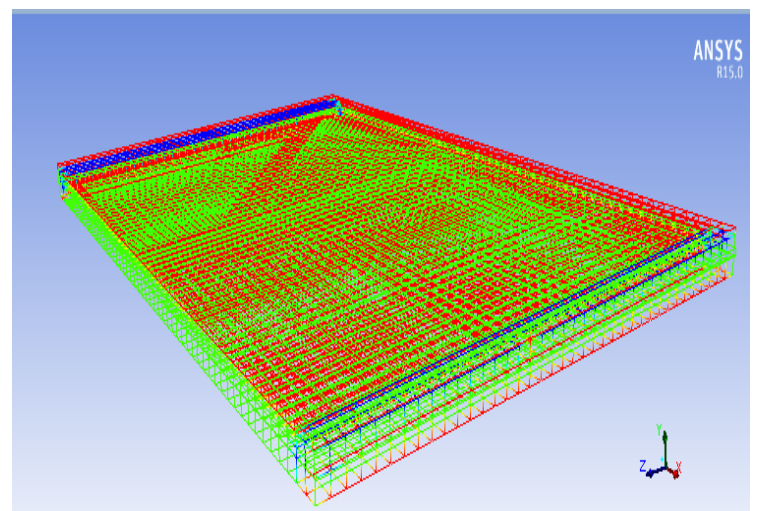

Fig. 6. Temperature supply in Grid View without PCM

Published By:

Blue Eyes Intelligence Engineering \& Sciences Publication

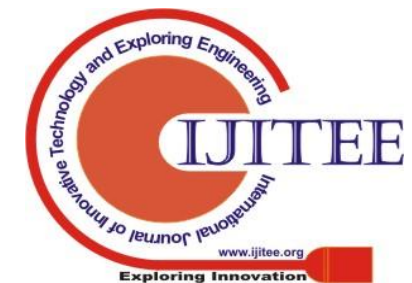




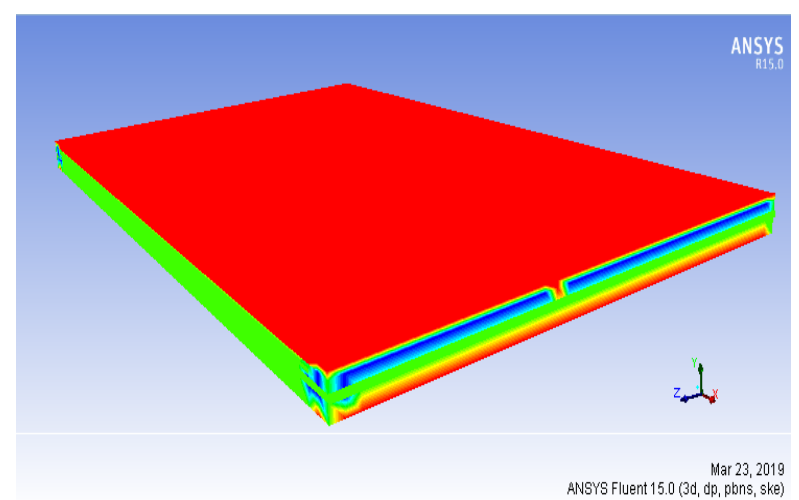

Fig. 7. In Normal View Without PCM of temperature distribution

Fig. 6 and 7 shows the temperature distribution around the PV panel for Spalart allmaras model and K-epsilon model over the Aluminium Layer respectively. It is observed that predicting the stalling effects from K-epsilon model with standard wall function and hence there is a match in CFD analysis results in the stalled region.

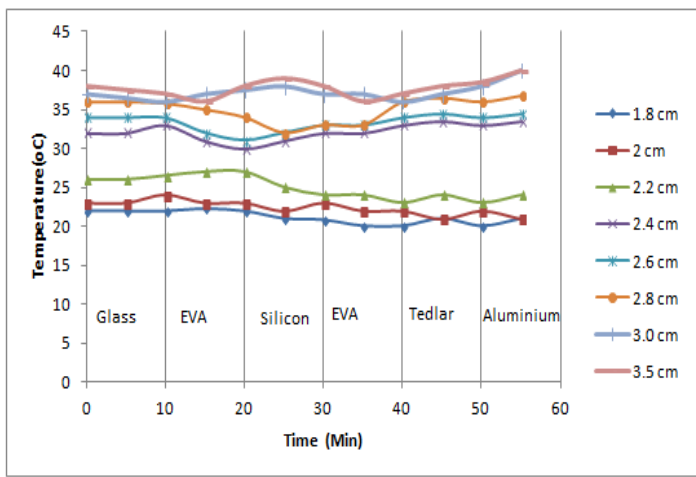

Fig. 8. PV temperature distribution ranges during winter weather condition

Fig 8 and 9 Shows the thermal performance of PV panel without PCM in an aluminium box and reported the front surface temperature glass to aluminium layers with winter and summer weather conditions.

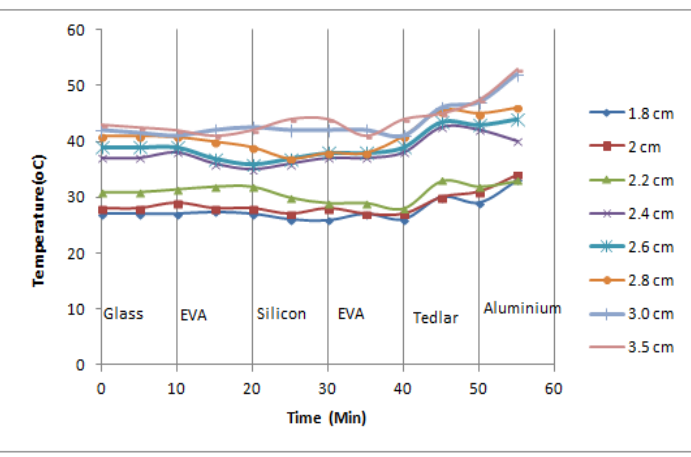

Fig. 9. PV temperature distribution ranges during summer weather condition

For justification, the calculations are done by current work methodology used by same parameters as it is. The variation in front surface temperature to aluminium with time is plotted in the fig. It's clearly noted that the temperature is increasing in glass surface and aluminium box. The ambient temperature as well as solar radiation intensity with variations can be noted in the layers with time respectively.

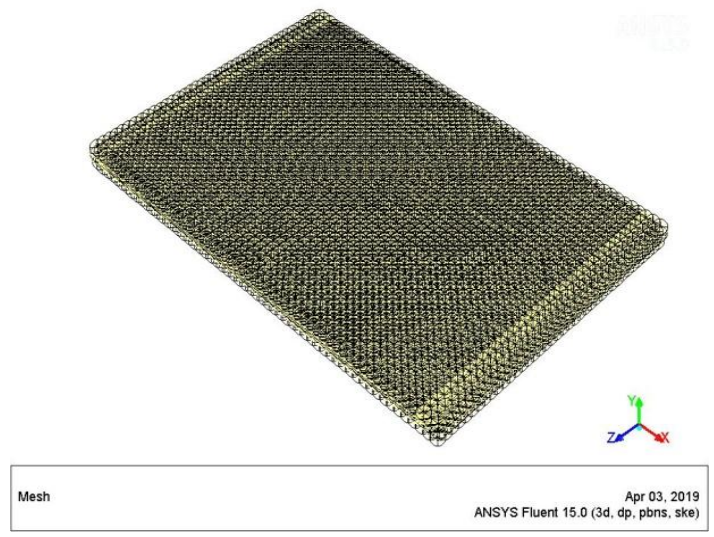

Fig. 10. Structure mesh of photovoltaic panel with PCM

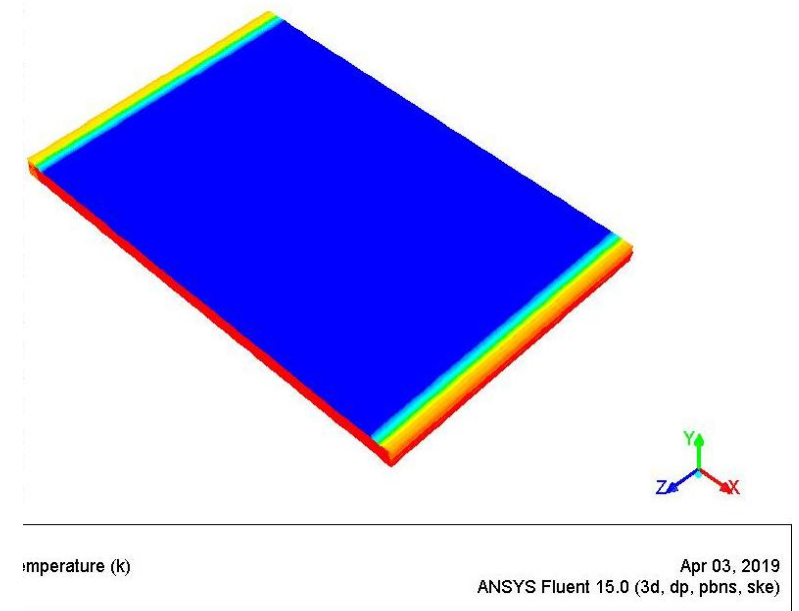

Fig. 11. Temperature Distribution in Normal View with PCM

Fig. 10 and 11 shows the temperature distribution around the PV-PCM panel model with standard wall function over the Aluminium Layer filled with PCM at backside respectively. It is observed that $\mathrm{K}$-epsilon model under predicts the stalling effects and hence there is a match in CFD analysis results in the stalled region.

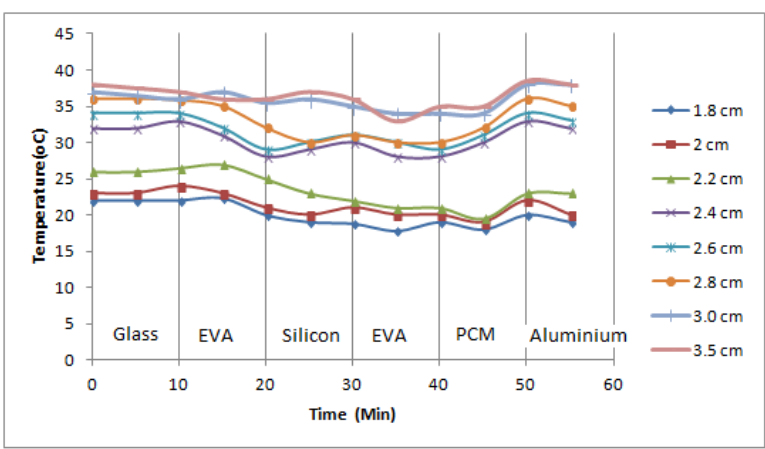

Fig. 12. PV-PCM temperature distribution ranges during winter weather condition 


\section{CFD Analysis of Phase Change Materials Integrated with Solar Photovoltaic Modules}

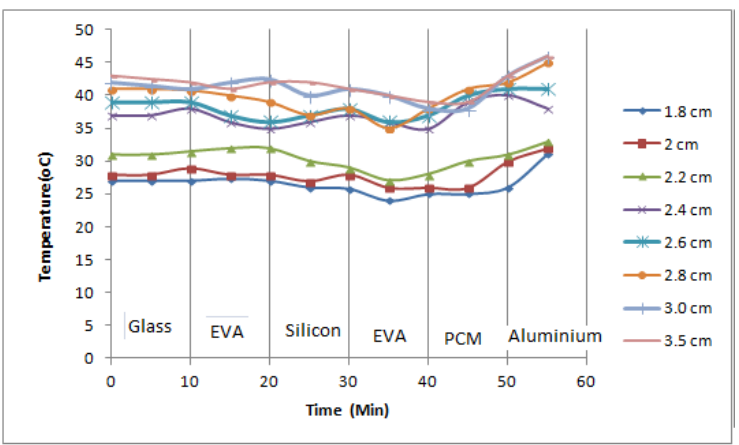

Fig. 13. PV temperature distribution for different thickness of material

Fig 12 and 13 shows the thermal performance of PV-PCM panel in an aluminium box is integrating and filled with PCM materials. The variation in the temperature of the front surface to aluminium with time is plotted. It's clearly noted that the temperature is decreasing in the PCM Surface due to that PCM solid to Liquid nature. Solar radiation intensity with variation and ambient temperature is noted in the layers with time respectively.

The 300 irradiation was run using the CFD analysis. The PV and ambient temperature were measured by using software analysis. First system consists of photovoltaic panel without PCM the temperature distribution in the glass surface and the aluminium box due to the materials properties of thermal conductivity as well as specific heat capacity. The other module which consists of photovoltaic panel fabricated with a phase change material provided a container (aluminium box) at the back side. The temperature distribution is decreased due to the effects of using PCMs in photovoltaic cell the materials properties of PCM density 1562 (liquid $32^{\circ} \mathrm{c}$ ) at initial stage to solid state 1802 (Solid $24^{\circ} \mathrm{c}$ ) then it changes to solid 1710 (solid, $25^{\circ} \mathrm{c}$ ). The thermal properties of PCM 0.540 (liquid, $38.7^{\circ} \mathrm{C}$ ) 1.088 (solid, $23^{\circ} \mathrm{C}$ ). The Comparison of the temperature trends of PV-PCM integrated modules and the time gives information about the rate of increase in temperature degree for the rising time intervals. The reduction in layer of PCM temperature module caused to heat distribution is slightly decreasing in the aluminum panel. So may be the electric output efficiency as maintained due to the integrating of PCM. The heat is absorbed by the PV-PCM modules and is stored as suppressed heat then the raise of temperature module is prevented.

\section{CONCLUSION}

Thus the model has been presented and analysed for the thermal performance of the PV panel without PCM design and with the model attached with phase change materials at the rear side in aluminium panel and heat transfer due to conduction from solid to solid materials like glass and aluminium panel are noted. The heat transfers due to convection from solid to liquid materials like PCM are also noted with two different weather conditions. The radiations of heat transfer were compared with time intervals and the following has been analysed.

(i) The graph is plotted for the temperature variation of in front surface to the aluminium plate and the time taken. From this, the temperature is increasing in glass surface and aluminium box. The ambient temperature based the solar radiation intensity is noted in the layers with time respectively.

. (ii) The graph is also plotted for the temperature variation in front surface to aluminium includes PCM and the time is shown in plot. This shows clearly that the temperature is decreasing in the PCM Surface due to that PCM solid to Liquid nature.

Thus it is proved that the presence of PCM increases the efficiency of the solar PV system.

\section{REFERENCES}

1. Amrit Om Nayak, G.Ramkumar, T.Manoj, and R.Vinod, "Comparative Study between Experimental Analysis and CFD Software Analysis of PCM material in Thermal Energy Storage System" International Journal of Chemical Engineering and Applications, vol. 2, no. 6, 2011.

2. S.A. Memon, "Phase change materials integrated in building walls: a state of the art review," Renew Sustain Energy Rev, vol.31, 2014, pp. 870-906.

3. Adityan, S., and A. Nalini. "Modeling of next generation standalone solar powered micro grid." International Journal of MC Square Scientific Research, vol. 9, no. 1, 2017, pp.72-77.

4. N.D. Patil, "Design and Analysis of Phase Change Material based thermal energy storage for active building cooling: a Review," International Journal of Engineering Science and Technology (IJEST), vol.4, no.6, 2012, pp.2502-2509.

5. A.H. Abedin, A.R. Marc, A Critical Review of Thermo-chemical Energy Storage Systems," The Open Renewable Energy Journal, vol. 4, pp. 42-46.

6. G. Pavlov, B.W. Olesen, "Building thermal energy storage- concepts and applications," Available at: http://orbit.dtu.dk/fedora/objects/orbit:72784/datastreams/file_638308 $8 /$ content, 2012.

7. S. Karthikeyan, S. Muthu Saravanan, R. Prashanth, "Energy conservation through phase change material based thermal energy storage system,"- $a$ project report, Anna University, 2006.

8. M. Ravikumar, Dr. P.S.S. Srinivasan, "Phase change material as a thermal energy storage material for cooling of building," Journal of Theoretical and Applied Information Technology, vol. 4, no. 6, pp. 503-512, 2008

9. B. Zalba, J.M. Marın, L.F. Cabeza, H. Mehling, "Review on thermal energy storage with phase change: materials, heat transfer analysis and applications," Applied Thermal Engineering vol. 23, 2003, pp.251-283.

10. Lavinia Gabriela SOCACIU, "Thermal Energy Storage with Phase Change Material," Leonardo Electronic Journal of Practices and Technologies, no. 20, 2012, pp. 75-98

11. M. Ravikumar, Dr. P.S.S. Srinivasan, "Natural cooling of building using phase change material," International Journal of Engineering and Technology, vol. 5, no.1, 2008, pp. 1-10,

12. S. Mondal, "Phase change materials for smart textiles- An overview," Applied Thermal Engineering, 2008, pp. 1536-1550.

13. V.B. Manimaran, "Design and Implementation of Solar-Wind Combo for Hybrid Energy Application," International Journal of MC Square Scientific Research, vol.5, no.1 Nov 2013, 37-42.

\section{AUTHORS PROFILE}

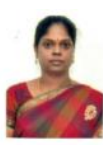

L. Chitra is an Associate Professor and Head in the department of EEE at Aarupadai Veedu Institute of Technology. She received her Bachelor Degree in Electronics and Instrumentation Engineering. She received her Master's Degree in Power Electronics and Drives in Anna University. She completed her PhD in Sathyabama Institute of Science and Technology in the field of Micro Electro Mechanical Systems for sensor design. Her research area includes MEMS, Renewable Energy, Process control, Sensors and Smart Sensors. She has published more than fifteen papers in International Conferences and Journals. She has a teaching experience of more than 18 years. She has received MNRE fund of Rs.1,50,000 for National Conference on Emerging Trends in New Renewable Energy Sources in the year 2014. She has also received a fund of Rs.1,00,000 from Unnat Bharat Abhiyan for Mobile Reverse osmosis based water purification system using Solar PV source for rural India in year 2019. She has also received a fund of Rs.50,000 from Unnat Bharat Abhiyan for DC Micro Grid based Solar PV generation to supply power to street lamp and common utilities in a village. 
Abhijeeth Singh born in Chennai, He has completed his Bachelor's Degree at Aarupadai Veedu Institute of Technology, Vinayaka Mission's Research Foundation, and Chennai. He has worked on many projects related to Renewable Energy, PLC, smart grid, Material analysis, Material Extraction Techniques, etc.,. He is one of the notable student in his college, for his interest in the field of Automation, Renewable Energy. His current research interests include power electronics, renewable energy, power transmission, PLC, Material Analysis, etc.

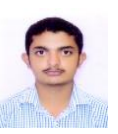

Prathyaman Sing was born in Chennai, He has completed his Bachelor's Degree at Aarupadai Veedu Institute of Technology, Vinayaka Mission's Research Foundation, Chennai. He has worked on many projects related to Renewable Energy, Material analysis, Material Extraction Techniques, etc., He is known to be an outstanding student for his interest in the field of Automation, Renewable Energy and Material Analysis. His current research interests include power electronics, renewable energy, power transmission, PLC, Material Analysis, etc. 